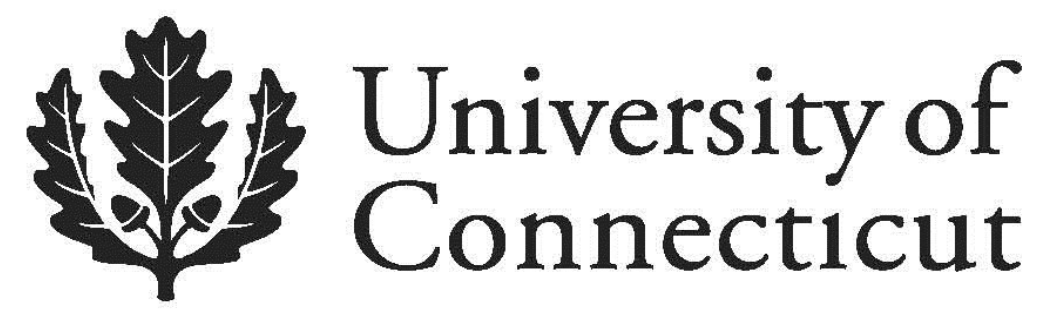

Department of Economics Working Paper Series

\title{
Unearthing T. Rex: The Law and Economics of Paleontological Finds
}

\author{
Paul Hallwood \\ University of Connecticut \\ Thomas J. Miceli \\ University of Connecticut
}

Working Paper 2014-07

April 2014

365 Fairfield Way, Unit 1063

Storrs, CT 06269-1063

Phone: (860) 486-3022

Fax: (860) 486-4463

http://www.econ.uconn.edu/

This working paper is indexed on RePEc, http://repec.org 


\title{
Unearthing T. Rex: \\ The Law and Economics of Paleontological Finds ${ }^{\dagger}$
}

by

Paul Hallwood* and Thomas J. Miceli**

\begin{abstract}
This paper assesses the economic characteristics of the balance that federal law aims to achieve between the interests of paleontologists and amateur and commercial collectors of fossils on US federal lands. The objective function is taken to be the maximization of the social value of these resources. Allowing 'open access' to amateurs and commercial collectors would maximize search activity. However, as a fossil's scientific value is not necessarily their priority, they may under-invest in the recovery of such information. We trace how US federal law has tried to strike a balance between search activity and scientific recovery. We also comment favorably on the developing trend of promoting professional (paleontologist)-amateur partnerships in both search and recovery.
\end{abstract}

Key words: Fossils, scientific value, search and recovery, paleontology JEL categories: D83, H41, I23, K11, O32

April 2014

*Professor, Department of Economics, University of Connecticut, Storrs, CT 06269; Ph: (860) 434-1064; Fax: (860) 781-6795; E-mail: Paul.Hallwood@uconn.edu.

**Professor, Department of Economics, University of Connecticut, Storrs, CT 06269; Ph: (860) 486-5810; (860) 486-4463; E-mail: Thomas.Miceli@uconn.edu.

${ }^{\dagger}$ In writing this paper, we have benefitted from conversations with paleontologists Jack Horner and Patrick Leiggi of the Museum of the Rockies, and archaeologist Michael Trimble of the Army Corp of Engineers, St. Louis. 


\section{Unearthing T. Rex: The Law and Economics of Paleontological Finds}

\section{1: Introduction}

This paper investigates the economic rationality of U.S. laws governing the collection of fossils on public lands. Many fossils are mixed goods combining private and public good values. Private good value is realized when the pecuniary value of a fossil is realized or if it enters directly into a private collection; public good values are created when a fossil-type and the information associated with it are added to the stock of scientific knowledge in the field of paleontology. The two values are not necessarily mutually exclusive, but the law governing rights to fossil finds will affect incentives for searching in the field and realization of these values.

Professional paleontologists practice an exact empirical science; a fossil with no record of its provenance is less valuable to science than one with a full record. Accurate dating of a fossil usually requires knowing in which geological stratum it was found. Paleontologists are also interested in taphonomy, or the grouping of fossils, which requires careful mapping of the remains on a site. The taphonomy may reveal how the animals died-for example, if in a single catastrophic event the bones will likely be jumbled together, whereas if they died separately over many years, they might be nicely aligned due to the actions of flowing water. Further, if a fossil grouping is of the same animal it may suggest herding behavior. Articulated skeletons are especially valuable to paleontology because they may reveal how an animal stood and its mode of locomotion. Excavation of these skeletons is particularly tricky, and "is best left to people familiar with dinosaur anatomy. Inexperienced collectors risk destroying or losing important elements"..."[A]rticulated skeletons commonly have associated skin impressions preserved 
around many of the bones. Preparation of the specimen must proceed extremely carefully and slowly to avoid destroying these scientifically important impressions" (Horner, 2001, p. 31). ${ }^{1}$

The main question investigated in this paper is: Do the relevant US laws as they apply to public lands (amounting to about 500-million acres, or, $29 \%$ of the USA) make economic sense when judged against the standard of attempting to maximize the mixed good values of paleontological resources? $?^{2}$ Our analysis emphasizes both the proper handling of fossils once they are found, as well as the design of the legal framework governing incentives to search for fossils in the first place. Our reading of the existing literature on paleontological law is that it virtually ignores the matter of promoting search-in-the-field. Yet without investment in search activity fewer fossils will be found.

In the 1980s professional paleontologists were not of one mind as to what new legislation was needed to promote the social value of fossils. The Society of Vertebrate Paleontology argued for strong protections of public good values, while a committee of the National Research Council (NRC) (1987) did not. The former argued for strict permitting requirements, depositing of finds in approved institutions, and no commercial collecting, whereas the latter argued that "the science of paleontology is best served by unimpeded access to fossils and fossil-bearing rocks in the field" (quoted by both Lazerwitz, 1994, and Sakurai, 1994). Its arguments were based on several factors: that reporting of finds would in any case have to be up to the highest standards of

\footnotetext{
${ }^{1}$ Bennington et al. (2009) give a more detailed description of record keeping in the associated field of paleoecology. Thus, "How were fossils obtained and enumerated...? Were bulk samples or bedding planes counted? What was the approximate volume or area of each sample? What was the screen size used when sieving samples? Was the density of fossils consistent from sample to sample, or did some samples require a larger volume or area to produce comparable numbers of fossils? Were all specimens counted or were subsamples counted? If the latter, how was the statistical robustness of sample estimates (diversity, frequencies, ratios) ensured...? How were fossils extracted from the matrix? Did the methods used to extract fossils introduce any biases caused by size, shape, density, differential mineralogy, or preservation ...? How were numbers of individual organisms estimated from bivalved and other multi-element fossils...? Were taxa represented by different numbers of body parts weighted differently in the analysis?" (p. 2).

${ }^{2}$ This paper does not discuss property law as it applies to fossils found on privately owned lands as there are apparently no restrictions on the disposition of such finds.
} 
academic journals; that recovery of finds should not be impeded by permitting requirements because the many specimens lying on the surface would weather away; and that given the vast scale of federal lands, policing would be ineffective. The NRC committee also supported collecting by amateurs as well as by commercial collectors, albeit with the requirement that scientifically important specimens be delivered to bone fide research institutions.

In our analysis we designate three classes of fossil collectors: professional paleontologists, commercial collectors who look to sell finds for a profit, and amateur collectors who operate out of interest rather than profit. Laws that exclude fossil collecting by either of the latter two groups risks under-investment in search; but unrestricted collecting activity by them risks under-investment in the recovery of scientific knowledge because it is usually not their main concern. It is unfortunate that any legal system governing fossil recovery is likely to involve a certain amount of waste-either sub-optimal search activity, or failure to maximize the accumulation of scientific knowledge as some fossils are 'spirited away' by the nonpaleontologists groups.

This is not to say that the paleontologists and non-paleontologists are 'daggers drawn,' as seems to be the case between 'treasure hunters' and underwater archaeologists in recovering values from historic shipwrecks (Hallwood and Miceli, 2006). For example, the University of Montana runs the Paleo Exploration Project as a professional development program for K-12 teachers in scientific fossil collecting techniques with the goal that the teachers, once trained, would take students into the field (Almquist, et al., 2009). Indeed, the paleontologist Jack Horner encourages amateur collecting while advising that the aid of experienced paleontologists should be sought; he even gives two examples of commercial collectors directing paleontologists to likely sites in the field (Horner, 2001). 
The financial cost of search and recovery is also relevant to our discussion. Museums and universities are financially constrained in what is an expensive business. For example, one senior practitioner estimating that of the $\$ 4$ million dollars spent by his museum in a recent year, all but $\$ 500,000$ came from private donations. ${ }^{3}$ No wonder that professional paleontologists are happy to share search costs with the other groups. Furthermore, non-profit organizations such as Earth Watch have sprung up to team professional paleontologists with amateurs on designated field projects. The amateurs gain the utility of contributing to gathering scientific information in the field, while the professional project leaders benefit from the labor of willing amateurs.

Another reason for the seemingly 'relaxed attitude' on the part of professional paleontologists toward search and collecting by non-scientists has to do with the relative abundance of fossils in the U.S. For example, Benson (1966) describes fossils in the "classic localities' of western Wyoming and southwestern Montana as "abundant"; similarly Williams (1973) with respect to North Central Utah, and Bennington et al. (2009, p. 1) refer to "the vast repository of paleoecological data." And to quote Horner again "I believe that we have found less than 1-percent of the different species of dinosaurs that once lived in this region [Montana]. There is so much more to discover and so much more dinosaur collecting history to be made!" (Horner, 2001, page 59). It is also the case that many fossils contain little if any public good value because they are already known to science and are plentiful. Thus, "there is certainly no shortage of invertebrates; they're practically inexhaustible. And vertebrates? Even T-Rexes aren't unique anymore. Simply put, fossils are not rare" (fossil hunter Tribold quoted Simmons (2005, p. 69).

\footnotetext{
${ }^{3}$ Conversation with Patrick Leiggi, Administrative Director of Paleontology, Museum of the Rockies, December $30^{\text {th }}, 2013$.
} 
We continue as follows. In section 2 we offer an economic model of optimal search and extraction of fossils. We use this model in section 3 to inform our discussion of the main laws that have been enacted or proposed for dealing with the recovery of paleontological values on public lands. Section 4 presents conclusions.

\section{2: Theoretical analysis}

The process of discovering valuable fossils proceeds in two stages. First, a potentially valuable fossil must be located, and second, it must be extracted and preserved. We consider the efficiency of both decisions, beginning with the recovery process once a fossil is located.

\subsection{Optimal Recovery of Fossils}

Regardless of who first locates a fossil, the process of extraction and recovery depends on both the commercial and scientific value of the specimen. To be concrete, we let $M$ denote the market, or commercial, value of a fossil once recovered, representing the maximum amount that a collector or museum would pay for it; and we let $S$ denote its scientific value, reflecting its value in advancing scientific knowledge. As noted, much (if not most) of $S$ is obtained in the recovery process, which preserves not only the fossil itself but also the characteristics of its location in the surrounding strata, its orientation, other artifacts found in the vicinity, and so on. The proper scientific procedure is therefore crucial in ensuring that $S$ is fully realized. This depends on the technology of recovery, which we discuss shortly. The value of fossils to amateur collectors is generally subjective, reflecting the utility that amateurs derive from the process of search and discovery, and therefore has no necessary relationship to $M$ or $S$. Thus, while we recognize the existence of this value, we abstract from it here. 
Regarding the recovery process, we suppose that there are two technologies. One, labeled $T_{0}$, represents the most efficient way to extract the fossil itself so as to preserve its market (or personal) value. Let the cost of extraction under this technology be $k_{0}$. When this technology is used, however, we assume that much of the scientific value is lost. Specifically, suppose that only a fraction $\alpha$ of $S$ is preserved by technology $T_{0}$, where $0 \leq \alpha<1$. Thus, when technology $T_{0}$ is used, the realized value of the recovered fossil is $M+\alpha S$.

In contrast, the second technology, labeled $T_{1}$, is specifically designed to preserve the scientific value of a fossil by ensuring that state-of-the-art excavation techniques are employed and all relevant data is recorded. As a result, the cost of extraction, $k_{1}$, is assumed to be higher (i.e., $k_{1}>k_{0}$ ). We assume, however, that the use of technology $T_{1}$ also preserves the market value of the fossil because once the scientific information has been gathered, the fossil itself can (theoretically) be sold. Thus, when technology $T_{1}$ is used, the resulting gross value of the fossil is $M+S$. Generally speaking, only trained scientists will have the knowledge and ability to use technology $T_{1}$.

The optimal recovery procedure depends on the particular values of $S$ and $M$ associated with a given find. We suppose that fossils can vary along both dimensions, but that the realized values can be observed with certainty at the time of discovery. Any find can therefore be described by its $(S, M)$ pair. The optimal extraction strategy will depend on how the realized values of $S$ and $M$ relate to the costs of extraction under the two technologies.

[Figure 1 and Table 1 here]

Given the preceding assumptions, Figure 1 identifies six possible regions based on the realized values of $S$ and $M$, and Table 1 summarizes the allowable recovery technologies in each 
of these regions based on the objective of maximizing the value of finds. ${ }^{4}$ Consider first regions I and II, in which $M+S<k_{1}$ and $M+\alpha S<k_{0}$. The realized value of fossils in these regions is not large enough to make recovery worthwhile for either commercial or scientific purposes, and as a result, there is no reason to impose any limits on recovery in these regions. Indeed, it is likely that most fossil recovery here will be by amateur collectors for their personal consumption.

Next, in region III, $M+\alpha S>k_{0}$ but $M+S<k_{1}$. In this case, the scientific value of fossils is not large enough to justify use of technology $T_{1}$, but the market value is large enough that $T_{0}$ yields a net social benefit. Still, because $M<k_{0}$ for some fossils in this region (specifically, those points in region III to the left of the dashed vertical line at $M=k_{0}$ ), commercial hunters will not find it profitable to recover all finds here, assuming that they cannot capture $S$. In any case, however, there is no reason to limit recovery in this region by either commercial or amateur collectors.

In region IV, $S+M>k_{1}$ and $M+\alpha S>k_{0}$, so both technologies produce a net benefit, but $S+M-k_{1}<M+\alpha S-k_{0}$, or

$$
S<\left[\left(k_{1}-k_{0}\right) /(1-\alpha)\right]
$$

Thus, the scientific value of fossils is sufficiently small that technology $T_{0}$ yields the higher return. Consequently, there is again no basis for limiting recovery, though, as was true in region III, commercial hunters will presumably only be interested in those fossils in region IV for which $M>k_{0}$

In region $\mathrm{V}$, both technologies again yield a positive return, but in this case $S+M-$

$$
\begin{aligned}
& k_{1}>M+\alpha S-k_{0}, \text { or } \\
& \quad S>\left[\left(k_{1}-k_{0}\right) /(1-\alpha)\right] .
\end{aligned}
$$

\footnotetext{
${ }^{4}$ We assume that $k_{0}>\alpha k_{1}$ to illustrate the maximum number of possible regions.
} 
Thus, the scientific value in this region is large enough that recovery by technology $T_{1}$ is socially optimal. And because $M>k_{0}$ for some fossils here, it would be necessary to prohibit the use of technology $T_{0}$ by commercial (and amateur) collectors to ensure that the scientific value of any finds is preserved. While this prohibition does not preclude search by commercial and amateur hunters, it would presumably require them to notify, or partner with, trained paleontologists for carrying out the recovery of any finds that they locate in this region.

Finally, in region VI, $S+M-k_{1}>0>M+\alpha S-k_{0}$. Thus, only technology $T_{1}$ yields a positive return. Further, because $M<k_{0}$ for all fossils in this region, commercial hunters presumably will voluntarily refrain from extraction. However, because amateur hunters may still find it personally advantageous to recover fossils in this region, preservation of scientific value requires a ban on their use of $T_{0}$ here as well. Again, any recovery would require partnering with trained paleontologists.

This completes the categorization of the different fossil finds regarding optimal recovery procedures once a fossil is located. The general conclusion is that when scientific and market value are low, no limitations on recovery are necessary, but when scientific value is sufficiently high (as dictated by the threshold condition in (2)), a prohibition on recovery by technology $T_{0}$ is necessary to prevent its use by commercial and amateur collectors.

A final point concerns the impact of programs described above that encourage amateur collectors to collaborate in the field with paleontologists, usually at little or no cost to the paleontologists. This has the effect of reducing $k_{1}$, which increases the size of regions V and VI in Figure 1 while shrinking the size of regions I-IV. These programs therefore expand the regions where technology $T_{1}$ is favored, and in that sense represent a kind of subsidy of the public good (scientific) value of fossils. 


\subsection{Search for Fossils}

The search for fossils is a costly and uncertain activity, similar to research aimed at developing product innovations (Mortensen, 1982), efforts to gain control of an open access resource (Lueck, 1995), or search for sunken shipwrecks (Hallwood and Miceli, 2006). Following this literature, we define the search technology by a function $p(x)$, which is the probability that a fossil will be located as a function of the expenditure on search, $x$, where $p^{\prime}>0$, $p "<0$. Thus greater search increases the probability of a discovery, but at a decreasing rate.

The incentives of the various collectors to invest in search depend on the prevailing law regarding any finds. Specifically, what legal claim do fossil hunters have regarding the disposition of finds, and what regulations (if any) dictate the extraction and recovery procedures that they must use?

Consider first the incentives of university-sponsored and other scientific searchers. Because their primary interest is the scientific value of any fossils they locate, they will necessarily internalize $S$. One supposes that they will also internalize the market value, $M$, because this represents a potential source of revenue, for example by increasing the flow of visitors to museums, that can help to fund their research. ${ }^{5}$ Thus, scientific searchers should have efficient incentives both for search and recovery, even in the absence of any legal restrictions.

As for amateur collectors, since we have assumed that their valuation of fossils is not systematically related to either $M$ or $S$, it is not possible to say much about their search behavior. In addition, one suspects that they will rarely stumble across scientifically important fossils, given that they will focus most of their search on known fossil beds that have already been wellsearched. However, when they do locate an important find, the prohibition on $T_{0}$ in the relevant

\footnotetext{
${ }^{5}$ It is possible, however, that scientists will not seek the highest market value for a find if that would involve sale to certain private collectors who would not necessarily make the artifact available for public display.
} 
regions will constrain their excessive use of that technology by requiring them to notify the appropriate authorities (assuming, that is, that they recognize scientifically important fossils when they find them).

Finally, the objective of commercial collectors is presumably to maximize the expected profits from the sale of any discoveries. This obviously requires that they acquire legal rights to any finds. Assuming that this is true-that is, assuming that there are no restrictions on recovery and sale — commercial collectors will extract a fossil using technology $T_{0}$ if and only if $M>k_{0}$. As for search, let us suppose that the market value $M$ is randomly distributed by the density $g(M)$, which is known. Thus, at the search stage, the commercial hunter will choose $x$ to maximize

$$
\begin{aligned}
& p(x) \operatorname{Pr}\left(M \geq k_{0}\right) \cdot E\left[M-k_{0} \mid M-k_{0}>0\right]-x \\
= & p(x) \int_{k_{0}}^{\infty}\left(M-k_{0}\right) g(M) d M-x,
\end{aligned}
$$

where the integral is the net expected commercial value of search. From a social perspective, this clearly involves too little search, first, because commercial hunters ignore the scientific value of those fossils that they expect to recover and sell; and second, because they ignore the scientific plus market of those fossils that they do not expect to recover (i.e., those for which $\left.M<k_{0}\right)$.

The preceding has assumed that commercial hunters obtain full property rights to any finds that they locate, but the previous section showed that optimal recovery entails a prohibition on the use of technology $T_{0}$ for scientifically important fossils (i.e., those in regions $\mathrm{V}$ and VI). Such a restriction will obviously further curtail search efforts by commercial hunters, either because it deprives them of rights to scientifically important fossils, or, if they retain rights to the 
commercial value of such finds after the scientific information has been gathered, because it raises their cost of extraction by compelling them to use technology $T_{1}$.

One final point regarding search concerns the possibility of excessive search if numerous collectors are competing in a "race" to find certain valuable specimens. The situation is possibly similar to an 'innovation race' (Mortensen, 1982) or the race to acquire property rights to a common resource (Lueck, 1995). However, this problem would not seem to be especially severe in the current context for two reasons. First, fossil hunters are not necessarily competing with one another to locate a particular specimen, and second, fossils in general are abundant, constituting what Lueck (1995, p. 405) calls a 'plenteous' good relative to the number of searchers. Thus, dissipation due to excessive search would not seem to be a serious concern.

\section{3: The principal acts governing recovery of fossils and artifacts}

\subsection{Federal Laws}

The Antiquities Act of 1906 was the first US federal law aimed at protecting the scientific value of items of antiquity on federal lands. The relevant aspects of the Act are summarized in the first row of Table 2. It can be interpreted as strongly promoting protection of scientific values as it required excavators to acquire permits issued by one of the Secretaries of the Interior, Agriculture, or Army. ${ }^{6}$ Further, permits could only be issued to institutions that were qualified to conduct excavations and "the examinations, excavations, and gatherings are undertaken for the benefit of reputable museums, universities, colleges, or other recognized scientific or educational institutions, with a view to increasing the knowledge of such objects, and that the gatherings

\footnotetext{
${ }^{6} 16$ U.S.C. 433 section 1 , and 16 U.S.C. 432 , section 3
} 
shall be made for permanent preservation in public museums". ${ }^{7}$ Clearly, this requirement was aimed at prohibiting the use of technology $T_{0}$.

This state of affairs changed in 1974, however, when the Ninth Circuit Court of Appeals in United States v. Diaz overturned the Antiquities Act, ${ }^{8}$ arguing that the phrase "object of antiquity" was unconstitutionally vague and did not explicitly apply to fossils. From that date until 2009, no single federal law governed fossil recovery from federal lands. Lazerwitz (1994), Sakuria (1994) and Malmsheimer and Hilfinger (2003) point out that the Bureau of Land Management, the National Parks Service and the Forest Service had their own regulations, but there were inconsistencies between them.

Following the failure of the Antiquities Act, several attempts were made in the US Congress, first in 1992 and then 1996, to write legislation providing a single governance regime for the collection of fossils on federal lands (see especially Malmsheimer and Hilfinger (2003) and Chew (2005)). These efforts were aimed at finding a balance regarding the extent to which fossil recovery on federal lands would be permitted by scientific practitioners, amateurs, and commercial collectors. An outline of the main details of these two Acts, both of which failed, is contained in the second and third rows of Table 2. It is striking that the 1992 Act aimed to promote amateur and scientific collecting to the exclusion of commercial collecting, whereas the 1996 Act allowed commercial collecting with the proviso that commercial collectors maintained 'dig records' and made important finds available to the scientific community-essentially requiring use of technology $T_{1}$ when warranted. Further, the 1996 Act, though it allowed the

\footnotetext{
${ }^{7} 16$ U.S.C. 432 , section 3. Offences against the Act were to be punished by fines of up to $\$ 500$ and/or up to 90-days in prison (16 U.S.C. 433, section 1).

${ }^{8}$ United States Court of Appeals, Ninth Circuit, June 24 ${ }^{\text {th }}, 1974$, United States v. Diaz, No 74-1177, 499 F.2d 113 (1974).
} 
commercial sale of fossils, required that they only be sold to museums or scientific institutions. Since private collectors will often pay more, this limited the market for commercial hunters.

[Table 2 here]

The absence of a controlling law was ultimately resolved by passage of the Paleontological Resources Preservation Act (P.L. 111-011) in 2009. (See the fourth row in Table 2.) Apart from allowing casual collecting by amateurs on federal land administered by the Bureau of Land Management, the Bureau of Reclamation, and the Forest Service (but not the Department of Defense), ${ }^{9}$ the Act is primarily designed to protect public good values (i.e. academic research and museum display) rather than private good values (private collection and sale of fossils). Permits are required and are issued only to qualified applicants for the purpose of furthering paleontological knowledge or for the education of the public. ${ }^{10}$ Moreover, any paleontological resource and associated records have to be deposited in an 'approved repository' such as a museum for curation. ${ }^{11}$ Violations such as excavation of fossils without a permit or their transportation, sale, or purchase entail criminal penalties. ${ }^{12}$ These include fines and imprisonment for up to five-years, and the doubling of these for second offences. Civil penalties can also be incurred, the size of which depends on factors such as the fair market value of a specimen and/or its cost of repair. ${ }^{13}$ Money raised through fines is used for paleontological-

\footnotetext{
${ }^{9}$ EC. 6304 , Collection of paleontological resources, paragraph a (2).

${ }^{10}$ EC. 6304, Collection of paleontological resources, paragraphs b (1), (2).

${ }^{11}$ EC 6305, Collection of paleontological resources.

${ }^{12}$ EC. 6306, Prohibited Acts; Criminal penalties. It is worth noting that even when arrests are made the Department of Justice often doesn't prosecute (conversation, January $2^{\text {nd }}$, 2014. with Michael K. Trimble, Ph.D, RPA, Director, Center of Expertise for Curation and Management of Archaeological Collections, US Army Corps of Engineers, St. Louis District. This affects calculations prior to a decision to illegally prospect for fossils. Thus, a 'treasure' hunter on public lands has to consider both the probability of being arrested, and the probability of being prosecuted if arrested.

${ }^{13}$ EC. 6307, paragraph d(1), (2) and (3).
} 
related work such as repair of damaged specimens, or to educate the public about paleontological resources and sites. ${ }^{14}$

\subsection{The (Failed )Montana "Compromise"}

An issue with federal law as applied to public lands is that while protecting scientific values, it reduces investment in prospecting by making illegal a private return on prospecting costs through the sale of fossils. In Montana, House Bill 392, State Park Excavation Bill, represented an attempt to deal with this latter issue (row five in Table 2). ${ }^{15}$ It was to apply to the excavation of fossils at Makoshika State Park - at 11,600 acres the largest state park in Montana. The aims of the Bill were to legalize and to raise private rates of return on fossil gathering in the Park; to promote and protect the collection of scientific values; and to raise funds for the State to contribute toward the cost of running the Park. Interpreted this way, the Bill can be seen as attempting to move toward the maximization of the mixed good values - private and public - of paleontological resources recoverable from the Park.

In this respect the most relevant part of the Bill is paragraph 5 revised of Section 22-3432. It reads:

Antiquities permits may be granted for the excavation and removal of paleontological remains at Makoshika State Park for the purpose of selling the paleontological remains and using revenue from the sale to benefit Makoshika State Park. Antiquities permits under this subsection must be used in accordance with rules pursuant to 23-1-102(5).

And,

The department [of Fish, Wild Life and Parks] may adopt rules establishing conditions for the use of antiquities permits granted pursuant to 22-3-432(5).

\footnotetext{
${ }^{14}$ EC. 6307, paragraph d (1), (2), (3).

15 The Bill was introduced by state representative Alan Doane in 2013.
} 
The first of these two paragraphs would open the park to the excavation and sale of fossil specimens, something that had hitherto not been allowed; and the second in effect says that the Department of Fish, Wild Life and Parks (DFW\&P) would set rules determining how revenues (if any) would be shared between the finder-seller and the State Park.

Though the bill was vetoed, it is possible to envisage how the State Park Excavation Bill might have worked. ${ }^{16}$ Prospectors would have been required to pay for an antiquities permit issued by the historic preservation officer of the Montana DFW\&P. These fees would have been a source of revenue for the state. ${ }^{17}$ Secondly, to protect scientific values, permits would be approved only for work to be carried out by museums, universities, other scientific institutions, as well as bone fide private individuals with skills in fossil excavation. A permit would specify that a summary report be written and furnished to the historic preservation officer containing relevant maps, drawings, documents and photographs. The preservation officer would determine what would be a reasonable period of time to recover scientific information given a site's morphology and other characteristics. Moreover, failure adequately to fulfill these requirements would mean that a permit would not be granted to an offending individual or institution in the future.

Thirdly, once the forgoing requirements were met, recovered fossil specimens could, according to the proposed law, be sold, thereby yielding a private rate of return to prospectors either institutions or private individuals. The extent to which the state of Montana would share in these revenues, so modifying the private rate of return, was left to rules still to be devised by the

\footnotetext{
${ }^{16}$ The full official name of the Act is "An act allowing for the excavation and sale of paleontological remains from Makoshika state park to benefit the park; granting rulemaking authority, amending sections 22-3-432 and 23-1-102, MCA; and providing a termination date."

${ }^{17}$ It is presumed that this officer would be well trained in the field of paleontology. By way of comparison it can be noted that preservation officers in the Department of Defense overseeing fossil recovery from DOD lands may well hold $\mathrm{PhDs}$ in the subject. Such a well trained official is necessary to 'police' the operation of the proposed system.
} 
DFW\&P. ${ }^{18}$ In any case, the provisions of the proposed Montana law most closely reflect the economic factors discussed in the previous section regarding both appropriate treatment of specimens once found, and the creation of incentives for private collectors and others to undertake costly search for fossils.

[Table 3 here]

\subsection{Summary}

The balance sought between paleontologist, amateur and commercial collectors by the preceding five acts is summarized in Table 3, where it is shown that three of them strongly favor paleontologists over commercial collectors while the other two allow somewhat greater scope for commercial collecting. Also, four of the five acts would have allowed collecting by amateurs provided that they worked with paleontologists if finds were of scientific interest.

It is clear that the primary purpose of all of the acts is the preservation of scientific value of fossils once discovered, with less attention (if any) paid to the incentives for investing in discovery in the first place. Although the Montana Bill contained fairly liberal policies regarding sale of fossils, it fell far short of creating anything close to optimal search incentives for commercial hunters, which could only be accomplished by subsidies or rewards to private searchers for scientifically valuable finds.

\section{4: Conclusions}

\footnotetext{
${ }^{18}$ The parallels between the vetoed Montana fossil-recovery law and the US law of salvage applied by the Admiralty courts overseeing recovery of treasure and scientific values from historic shipwrecks is quite striking. First, as Hallwood and Miceli (2006) explain, the Admiralty courts aim to balance the recovery of private (treasure) values and public (scientific archaeological) values from sunken wrecks. Neither is prioritized over the other. Secondly, property rights to work over sunken wrecks are granted to private companies working on federal (submerged) lands. Thirdly, the admiralty courts promote the collection of sound archaeological knowledge from a historic shipwreck through two devices: variation in the percentage of treasure value retained by a salvage company depending on the quality of work performed; and, cases of poor or nonexistent archaeological work, applications for permits in the future can be denied.
} 
We have seen how federal legislation has navigated from very strong protection of scientific values of fossils on federal land under the Antiquities Act of 1906, through a period of wavering between maintaining the same strong protection under the failed Vertebrate Paleontological Resources Protection Act of 1992, and the provision of greater scope for amateur and commercial collectors under the Fossil Preservation Act of 1996, which also failed. The Paleontological Resources Preservation Act that passed Congress in 2009 has for now settled the matter largely in favor of the protection of scientific values, while also allowing scope for amateur collectors to act in partnership with professional scientists. However, as Montana's vetoed State Park Excavation Bill of 2013 exemplifies, this legal equilibrium is not exactly 'cast in stone' as there is still a sentiment to allow greater scope for commercial collecting, at least on state lands.

Our analysis has shown that laws protecting scientific value are warranted based on the public good nature of this value, but these potentially create an offsetting disincentive for profitmotivated collectors to engage in search. Thus, if the scientific community has to rely at least to some extent on private collectors to locate important fossils, there needs to be some recognition of the incentives that those searchers face. We have also noted the benefit of professional paleontologists 'employing' amateurs in the field not only as low-cost search agents, but also as low-cost recovery experts when they work on-site in teams under the direction of professionals. Our view is that non-profit organizations such as Earth Watch perform an important function in they operate as brokers between professional paleontologists looking to reduce site-operating costs $\left(k_{1}\right)$, and amateurs looking for intellectual outlets. 


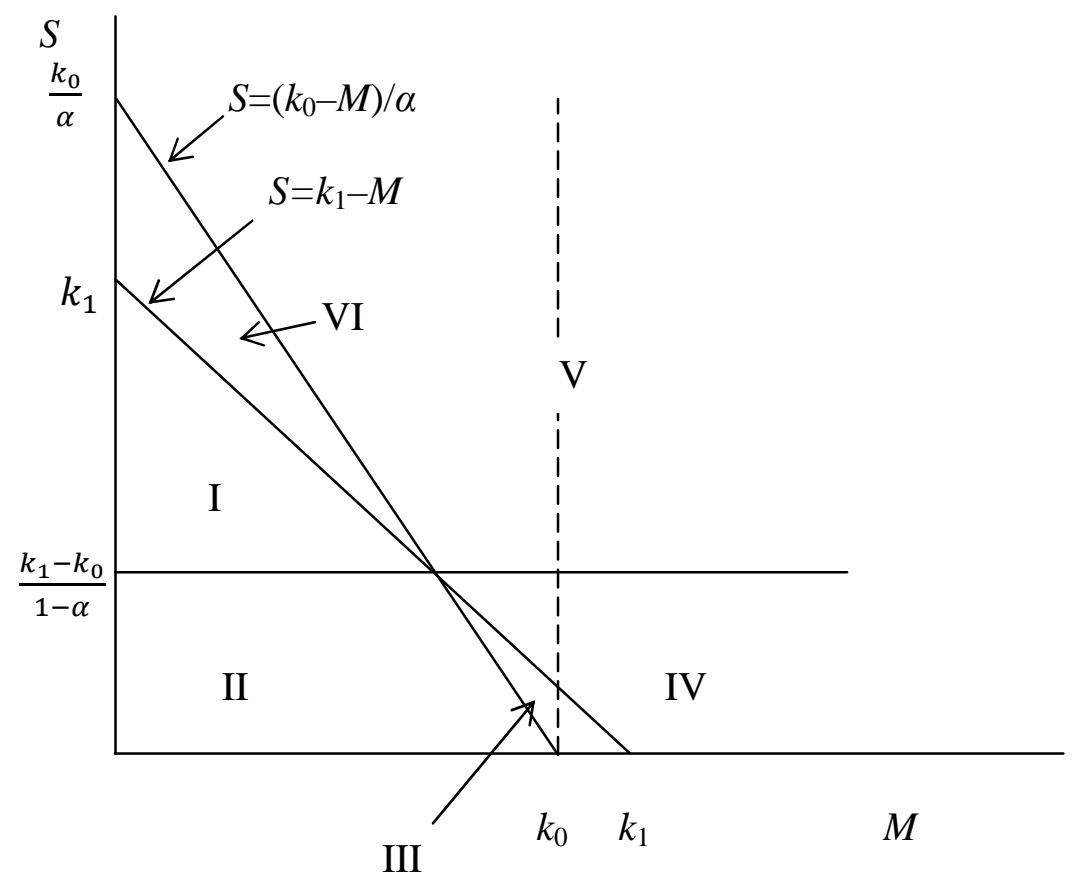

Figure 1. Categorization of fossils by market and scientific value. 
Table 1. Allowable Recovery Procedures by Fossil Type

\begin{tabular}{|c|c|c|}
\hline Region & Values & bble Technology \\
\hline I and II & $\begin{array}{l}M+S<k_{1} \\
M+\alpha S<k_{0}\end{array}$ & $T_{0}$ and $T_{1}$ \\
\hline III & $\begin{array}{l}M+S<k_{1} \\
M+\alpha S>k_{0}\end{array}$ & $T_{0}$ and $T_{1}$ \\
\hline IV & $\begin{array}{l}M+S>k_{1} \\
M+\alpha S>k_{0} \\
S<\left[\left(k_{1}-k_{0}\right) /(1-\alpha)\right]\end{array}$ & $T_{0}$ and $T_{1}$ \\
\hline V & $\begin{array}{l}M+S>k_{1} \\
M+\alpha S>k_{0} \\
S>\left[\left(k_{1}-k_{0}\right) /(1-\alpha)\right]\end{array}$ & $T_{1}$ only \\
\hline VI & $\begin{array}{l}M+S>k_{1} \\
M+\alpha S<k_{0} \\
S>\left[\left(k_{1}-k_{0}\right) /(1-\alpha)\right]\end{array}$ & $T_{1}$ only \\
\hline
\end{tabular}


Table 2: Summary of the Various Paleontological Acts

\begin{tabular}{|c|c|c|c|c|c|}
\hline & $\begin{array}{l}\text { Amateur } \\
\text { collecting }\end{array}$ & Permits & $\begin{array}{l}\text { Commercial } \\
\text { collecting }\end{array}$ & $\begin{array}{l}\text { Penalties for } \\
\text { violation }\end{array}$ & Main Objectives \\
\hline $\begin{array}{l}\text { Antiquities Act, } 1906 . \\
\text { Rendered } \\
\text { unconstitutional, } 1974 .\end{array}$ & No & $\begin{array}{l}\text { Yes. Only for } \\
\text { "reputable } \\
\text { museums, } \\
\text { universities, } \\
\text { colleges, or other } \\
\text { recognized } \\
\text { scientific or } \\
\text { educational } \\
\text { institutions" (Sec } \\
\text { 3). }\end{array}$ & No & $\begin{array}{l}\text { Fine up to } \\
\$ 500, \\
\text { imprisonment } \\
\text { up to } 90 \text {-days }\end{array}$ & $\begin{array}{l}\text { "...increasing the } \\
\text { knowledge of such } \\
\text { objects [of antiquity], and } \\
\text { that the gatherings shall } \\
\text { be made for permanent } \\
\text { preservation in public } \\
\text { museums" (Sec. 3). }\end{array}$ \\
\hline $\begin{array}{l}\text { Vertebrate } \\
\text { Paleontological } \\
\text { Resources Protection } \\
\text { Act, introduced } 1992 . \\
\text { Bill failed. }\end{array}$ & $\begin{array}{l}\text { Allowed. Finds } \\
\text { to be reported } \\
\text { to the Federal } \\
\text { Land manager. } \\
\text { Can retain if of } \\
\text { no scientific } \\
\text { value. Must } \\
\text { remain the } \\
\text { property of the } \\
\text { US, cannot sell } \\
\text { specimens. }\end{array}$ & $\begin{array}{l}\text { Yes. Only } \\
\text { granted for } \\
\text { scientific } \\
\text { research and } \\
\text { collecting; } \\
\text { required at the } \\
\text { excavation stage. }\end{array}$ & $\begin{array}{l}\text { Not allowed. } \\
\text { Rewards for } \\
\text { information } \\
\text { leading to } \\
\text { convictions }\end{array}$ & $\begin{array}{l}1^{\text {st }} \text { offence: } \\
\text { max fine of } \\
\$ 10 \mathrm{~K}, \text { and/or } \\
\text { up } 1 \mathrm{yr} \text { prison. } \\
\text { Double if } \\
\text { fossil value }> \\
\$ 500 ; 2^{\text {nd }} \\
\text { offence: fine } \\
\text { up to } \$ 100 \mathrm{k}, \\
\text { and/or up to } 5 \\
\text { yrs prison. }\end{array}$ & $\begin{array}{l}\text { To protect scientific } \\
\text { values, and to eliminate } \\
\text { commercial collecting. }\end{array}$ \\
\hline $\begin{array}{l}\text { Fossil Preservation Act, } \\
\text { introduced 1996. Bill } \\
\text { failed. }\end{array}$ & Yes. & $\begin{array}{l}\text { Yes, 'the } \\
\text { commercial } \\
\text { Collecting } \\
\text { permit', to be } \\
\text { sold at the } \\
\text { excavation stage. } \\
\text { "Federal lands } \\
\text { shall be open to } \\
\text { fossil collecting by } \\
\text { recon- } \\
\text { naissance without } \\
\text { a permit" (Sec 4) }\end{array}$ & $\begin{array}{l}\text { Allowed. } \\
\text { A National } \\
\text { Fossil Council } \\
\text { would } \\
\text { determine the } \\
\text { uniqueness of } \\
\text { specimens. } \\
\text { New specimen } \\
\text { types would } \\
\text { have to be } \\
\text { deposited with } \\
\text { a museum or } \\
\text { other scientific } \\
\text { institution. }\end{array}$ & $\begin{array}{l}\text { Civil penalties } \\
\text { of up to } \\
\$ 100,000 . \text { No } \\
\text { criminal } \\
\text { penalties. }\end{array}$ & $\begin{array}{l}\text { To raise money in fees } \\
\text { and royalties for the } \\
\text { federal government; to } \\
\text { promote access; to collect } \\
\text { specimens before they } \\
\text { weather away; to } \\
\text { encourage science as } \\
\text { excavations had to be } \\
\text { recorded and and records } \\
\text { deposited with the US } \\
\text { Geological Survey. }\end{array}$ \\
\hline $\begin{array}{l}\text { Paleontological } \\
\text { Resources Preservation } \\
\text { Act, introduced } 2002 . \\
\text { Passed in } 2009 .\end{array}$ & $\begin{array}{l}\text { Yes, under the } \\
\text { "casual } \\
\text { collecting } \\
\text { exception" }\end{array}$ & $\begin{array}{l}\text { Yes, only for } \\
\text { scientific } \\
\text { research and } \\
\text { amateur } \\
\text { collecting, } \\
\text { required for } \\
\text { excavation. }\end{array}$ & $\begin{array}{l}\text { No. Illegal to } \\
\text { sell or buy } \\
\text { fossils that a } \\
\text { person should } \\
\text { have known } \\
\text { had been } \\
\text { illegally } \\
\text { acquired. }\end{array}$ & $\begin{array}{l}\text { Civil and } \\
\text { criminal } \\
\text { penalties }\end{array}$ & $\begin{array}{l}\text { To promote scientific } \\
\text { research. }\end{array}$ \\
\hline $\begin{array}{l}\text { Montana House Bill } \\
\text { 392, State Park } \\
\text { Excavation Bill. Passed } \\
\text { an d vetoed } 2013 .\end{array}$ & Yes. & $\begin{array}{l}\text { Yes, including } \\
\text { commercial } \\
\text { collecting by } \\
\text { bone fide } \\
\text { individuals, } \\
\text { required at the } \\
\text { excavation stage }\end{array}$ & $\begin{array}{l}\text { Yes. } \\
\text { Paleontologica } \\
1 \text { records to be } \\
\text { kept and } \\
\text { deposited with } \\
\text { a scientific } \\
\text { institution } \\
\end{array}$ & & $\begin{array}{l}\text { To promote private search } \\
\text { and collection in } \\
\text { Makoshika State Park, } \\
\text { MT. To promote scientific } \\
\text { collecting, to raise income } \\
\text { for the Park. }\end{array}$ \\
\hline
\end{tabular}


Table 3: Comparison of the Various Acts

\begin{tabular}{|l|c|c|c|}
\hline & $\begin{array}{l}\text { At least some } \\
\text { prohibition on } T_{0}\end{array}$ & $\begin{array}{l}\text { Amateur collecting } \\
\text { allowed }\end{array}$ & $\begin{array}{l}\text { Commercial } \\
\text { collecting and sale } \\
\text { allowed }\end{array}$ \\
\hline $\begin{array}{l}\text { Antiquities Act, } \\
\text { 1906, Ruled } \\
\text { unconstitutional, } \\
1974 .\end{array}$ & Yes & No & No \\
\hline $\begin{array}{l}\text { Vertebrate } \\
\text { Paleontological } \\
\text { Resources } \\
\begin{array}{l}\text { Protection Act, } \\
\text { introduced in1992. }\end{array}\end{array}$ & Yes & Yes & No \\
\hline $\begin{array}{l}\text { Fossil Preservation } \\
\text { Act, introduced in } \\
1996 .\end{array}$ & Yes & Yes & Limited* \\
\hline $\begin{array}{l}\text { Paleontological } \\
\text { Resources } \\
\text { Preservation Act, } \\
\text { passed in 2009. }\end{array}$ & Yes & Yes & No \\
\hline $\begin{array}{l}\text { Montana House Bill } \\
\text { 392, State Park } \\
\begin{array}{l}\text { Excavation Bill, } \\
\text { 2013 }\end{array}\end{array}$ & Yes & Yes & Yes \\
\hline
\end{tabular}

*Sale allowed only to a museum or scientific institution. 


\section{References}

Almquist, H., Blank, L., Crews, J., Gummer, E., Hanfling, S. and Yeagley, P. (2009).

"Embedding Spatial Technology in a Field-Based Science Education Course for Teachers". In I. Gibson et al. (Eds.), Proceedings of Society for Information Technology \& Teacher Education International Conference 2009 (pp. 3708-3713). Chesapeake, VA: AACE. Retrieved February 13, 2014 from www.editlib.org/p/31229.

Bennington, J.R. et al. (2009), "Critical Issues of Scale in Paleoecology”, Palaios, 24 (1), 1-4.

Benson, A.L. (1966), "Devonian Stratigraphy of Western Wyoming and Adjacent Areas", AAPG Bulletin, 50 (12), 2566-2603.

Chew, A. Z. (2005), "Nothing Remains: Preserving the Scientific and Cultural Value of Paleontological Resources in the United States", Duke Law Journal, 54, 4, 1031-1060.

Hallwood, P. and Miceli, T. (2006), "Murky Waters: The Law and Economics of Salvaging Historic Wrecks”, Journal of Legal Studies, 35 (2), 285-302.

Horner, J. (2001), Dinosaurs Under the Big Sky, Mountain Press Publishing Company,

Lazerwitz, D.J. (1994), "Bones of Contention: The Regulation of Paleontological Resources on the Federal Public Lands", Indiana Law Journal, 69, 2, Article 8, 601-636.

Lueck, D. (1995), "The Rule of First Possession and the Design of the Law", Journal of Law and Economics, 38, 393-436.

Malmsheimer, R. W. and Hilfinger, A.S.H. (2003), "In Search of a Paleontological Resource Policy for Federal Lands", Natural Resources Journal, 43, 587 - 614.

Mortensen, D. (1982), "Property Rights in Mating, Racing, and Related Games", American Economic Review, 72, 968-979.

National Research Council (1987), Committee on Guidelines for Paleontological Collecting, National Academies Press.

Sakurai, D.S. (1994), “Animal, Mineral or Cultural Antiquity? The Management and Protection of Paleontological Resources”, Loyola L.A. International and Comparative Law Review, 197 243.

Shapiro, R.S., Fricke, H.C. and Fox, K. (2009), "Dinosaur-Bearing Oncoids from Empemeral Lakes of the Lower Cretaceous Cedar Mountain Formation, Utah", Palaios, January, 24, 51-58.

Simons, L. M. (2005), "Fossil Wars: a Dispatch from the Front Lines", National Geographic, 207, 5, May, 48-69. 
Williams, J. W. (1973), "Fossil Distribution across the Middle-Upper Devonian Boundary,

Portage and Logan Canyons, North-Central Utah", Geological Society of America Bulletin, May, 84, 1699-1704. 